\title{
Economic analysis of floodplain aquaculture at Daudkandi upazilla in Comilla
}

\author{
K. J. Chandra, D. Sarker, M. A. Khaleque ${ }^{1}$ and D. R. Das \\ Department of Aquaculture, Bangladesh Agricultural University Mymensingh-2202, Bangladesh, ${ }^{1}$ Department of \\ Fisheries (DoF), Matsya Bhavan, Ramna, Dhaka
}

\begin{abstract}
An economic anylysis was made to determine the cost of fish production in the floodplains at Daudkandi Upazilla in Comilla district during the period form January to April, 2007. Survey method was followed to collect data from 20 floodplain aquaculture projects. The projects record books and personal interviews of the NGOs and Fisheries officers were the main instruments of data collection. Statistical tools such as: range, mean, standard deviation and percentage were employed for analysis of data. The Cobb-Douglas production function model was used to estimate the values of co-efficients and related statistics of production function of fish culture in floodplains. Out of eleven explanatory variables, seven co-efficients had positive sign while only four co-efficients showed negative sign. The co-efficients bearing positive sign i.e., embankment construction, nursery and land lease, fertilizer and lime, fingerlings, feed, labor and staff wages and miscellaneous cost made positive impact on the farm income, while the co-efficients having negative sign i.e., area of floodplain, Office management, compensation and harvesting and marketing cost decreased the farm income. Summation of the production co-efficients i.e., return to scale ( $\sum$ bi) was found 1.023 which implies that per one taka investment in floodplain fish culture will give rise to a profit of Tk. 1.02 . The value of $R^{2}$ was found 0.892 , which means that the variations in farm income could be explained to the extent of $89.2 \%$ by the included variables. The remaining $10.8 \%$ variations could not be accounted for by the multiple regression analysis. Average fish production in the selected floodplains was $2920.43 \mathrm{~kg} / \mathrm{ha}$ of which production of cultured fish and indigenous fish was 2697.35 and $223.08 \mathrm{~kg} / \mathrm{ha}$ respectively. The cost of fish production, total return and net income were estimated Tk. 1,153,08.55, 1,76,385.49 and 61,076.94 /ha. respectively. Benefit cost ratio was found 1.53 .
\end{abstract}

Keywords: Floodplain, Aquaculture, Economic analysis, Resource productivity, Community

\section{Introduction}

Aquaculture could be one of the best options for the rural people, which can generate income, employment and food security and can contribute significantly to alleviate rural poverty. The growth and successes in aquaculture is replenished from about 0.5 million ha. of inland water area including ponds, ditches, oxbow lakes and coastal shrimp farms. Whereas there remains about 2.8 million ha. floodplain area having very negligible contribution in total fish production. The current production level in floodplain area is only $176 \mathrm{~kg} / \mathrm{ha}$ (DoF, 2004), which can be increased ten folds with minimum institutional support, but sincere and co-ordinated efforts are required from the community. On the contrary, if fish production can be increased 1.5mt/ha, about 12 lakh $\mathrm{mt}$ fish would be added to our national fish production. If five persons are involved in the fish production activities per ha, it will create the employment opportunity for about 40,000 people per year (Khaleque, 2006). About one-third lower areas of Bangladesh become inundated during rainy season. The areas of the country which become flooded and hold water for 4-5 months is termed as floodplain. Some parts of these are rice fields. Although the fish production from inland water increased but the total production from floodplains and beels decreased from $63 \%$ to $46 \%$ (DoF, 2006).

Bangladesh is a country with vast floodplains (Ahmed, 1997) and one of the world's most important wetlands (Khan, 1997). These wetlands provide habitats to hundreds of fish, plants, birds and other wildlife species and most importantly, a source of income for millions of rural people (MACH, 1999; DFID, 2000). The floodplain provides habitat in the form of feeding, breeding and nursery ground for a wide range of wild life including fish (Tsai and Ali, 1997). However, there has been a gradual decline in the production of fish from floodplains over the last two decades due to the reduction of wetlands and biodiversity, over fishing, siltation and management problem (Middendorp and Balarin, 1999). The floodplain aquaculture projects can conserve local biodiversity in better way. Once the projects are filled 
with floodwater from the neighboring river or canals, there happens automatic introduction of all kinds of natural fish available in local habitat. At the onset of monsoon, the fish can breed; spawn can grow and survive safely because of no public fishing takes place inside the project. On the other hand, free access in open water allows fishing by using all types of gears. In case of floodplain aquaculture projects, the ditches are not dried completely which allows some residual fish in the super market. Koi, Magur, Shing, Shol, Foli etc. are the live fish variety sold in city market at 4-5 times higher price than the cultured fish.

The economic study of aquaculture provides a basis for decision making for fish farmers and assists in formulation of public policies. However, in many developing countries such interest and the capacity to carry out extensive economic studies is presently lacking, thus making it difficult for sound development policies to be formulated (Shang, 1981). Many factors are involved in affecting the aquacultural economics. Bayley (1988) estimated the maximum potential yields is more highly exploited tropical floodplains at $110-160 \mathrm{~kg} / \mathrm{ha} / \mathrm{yr}$ while Mollah (2001) reported that it is possible to increase production up to $1976 \mathrm{~kg} / \mathrm{ha} / \mathrm{yr}$ by seasonal fish culture in floodplains. Recent research also shows that most of the floodplains in Bangladesh are not cultured in a planed way as like as Daudkandi area. Floodplain aquaculture practice in Daudkandi areas has emerged as an advanced approach of aquaculture compare to the traditional practices, which ensures community participation through a well-set organization with possible best use of local resources. Other than its commercial importance, the model of floodplain has multidisciplinary involvement like, conservation of aquatic biota, socio-economic upliftment of the community people, environment, cropping pattern and food production etc. With the above background the present study may be useful both at micro and macro level. The study is expected to provide some valuable information to the floodplain farmers and organizations dealing with such project. It is expected that the findings of the work will be helpful to prepare a guideline for a sustainable floodplain aquaculture practices. The work was therefore, initiated with the following objectives: 1 . to determine the potentiality of floodplain fish culture in the selected areas, 2. to determine per hectare cost and return, 3. to determine the factors affecting costs and returns and to measure resource productivity, and 4. to compare the profitability between floodplain fish production and existing bank interest.

\section{Materials and Methods}

For the present study survey method was used. Repeated visits were made to collect data in the study area both from every project individually and from the authority of SHISUK (Shikkha Shastha Unnayan Karzakram NGO working at the study area). The area in which a farm business survey is to be carried out depends on the particular purpose of the survey and possible co-operation from the farmers. Thus some selected floodplain aquaculture projects at Daudkandi upazilla in Comilla District were selected. Primary information was collected from Divisional Fisheries Office, Comilla regarding the concentration of area for floodplain fisheries.

This area was treated as a proper model of floodplain fishery by Depertment of Fisheries (DoF) and it was well known all over Bangladesh. There were heavy concentrations of floodplain fishery projects. Twenty floodplains were selected randomly to collect informations. The selected area was Goalmari, Eliotgonj (north), Eligtgonj (south), Suhinpur (west), Mohammodpur and Roypur union at Daudkandi upazilla in Comilla district. A questionnaire was prepared after correction and judged by the advisory committee. Some parts of the draft questionnaire were improved, re-arranged and modified in the light of the practical experience gained from the pre-testing. The collection of data covered a whole production period (June to November, 2006) of fish culture in floodplains. However, the formal data was collected by a field survey that was conducted from January to April 2007. At the time of interview the researchers asked questions systematically and explained whenever it was felt necessary. The data utilized in the present study were collected from the respective NGO SISHUK, Upazilla Fisheries Office, from floodplain projects' offices and the selected floodplains. Data was mainly collected from official records of the individual projects. Data was verified by discussing with the local peoples and also with the upazilla Fisheries Officer as well as with the Deputy Director of Chittagong. 
All the data were processed for analysis. The collected data were transferred to a master sheet and computed with a view to facilitation tabulation. Classified tables were prepared in keeping with the objectives. The tabulated data were then analyzed and condensed by using hectarage, average, percentage etc. A tabular method of analysis was mainly followed in analyzing the collected information to assess the effect of using inputs and other related factors of floodplain fish culture. Profitability of floodplain fish production was determined on the gross margin and net return analysis. Factors affecting the production of fish in floodplains. In the study area for production of fish the following inputs namely, fertilizer, feeds, lime, fish fingerlings, human labor, and miscellaneous cost were employed, which were considered as a priority explanatory variables and those explanatory variables were responsible for producing fish. Multiple regression analysis was conducted to explore the possible relationship between the production of fish and the input used. All information collected regarding floodplain fish culture operations were converted in hectare term.

Econometric techniques including the multiple regression and Cobb-Douglas production model were applied for determining the effects of various production inputs on output. In order to highlight the intensity and use of various production inputs under floodplain fish culture and management practices, a detail breakdown of the structural cost component is made as back up information to the Cobb-Douglas production function model. Eleven explanatory variables concerning production inputs were hypothesized to explain the fish production in the study area. The Cobb-Douglas function used for analysis (Heady and Dillion, 1966) is shown below:

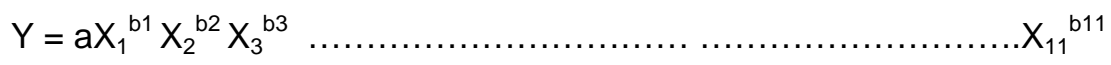

$\log Y=\log a+b_{1} \log X_{1}+b_{2} \log X_{2}+b_{3} \log X_{3} \ldots \ldots \ldots \ldots+b_{11} \log X_{11} \sum l$

Where $Y=$ Total income (Tk.), $X_{1}=$ Area of the floodplain (ha), $X_{2}=$ Cost of embankment repairing, $X_{3}=$ Cost of nursery and land lease, $X_{4}=$ Cost of fertilizer and lime, $X_{5}=$ Cost of fingerlings, $X_{6}=$ Cost of feed, $X_{7}=$ Cost of office management, $X_{8}=$ Cost of labour and staff wages, $X_{9}=$ Cost of crop compensation, $\mathrm{X}_{10}=$ Cost of harvesting and marketing and, $\mathrm{X}_{11}=$ Cost of miscellaneous, $\Sigma \mathrm{bi}=$ production co-efficient to be determined, $\mathrm{i}=1,2,3, \ldots \ldots 11$ and $\mathrm{a}=$ Constant. Management factor was also included in the estimated model as it was an importance input. A larger portion of the total input was utilized for such as, office set up, purchasing of furniture and other equipments. Total expenditure of the honorary was also included in this estimation.

\section{Results and Discussion}

In order to earn a respectable income, production cost becomes an important factor and accordingly it plays a dominant role in the decision-making process of the project operators. Therefore, in order to have a comparative economic picture of production of fish at the five different floodplains, costs and returns were calculated. All the costs and returns were accounted for the whole production time including farm preparation to marketing of fish.

\section{Production costs}

The costs of fish production included the cost items like- embankment/road construction and or repair, human labor, material inputs (includes cost of fertilizer and lime, feed and fingerling, office set up) and miscellaneous are mentioned in Table 1 . The amount of various cost items and contribution of different cost items to the total cost (percentage) has been illustrated. It required a minimum cost for the development of embankment or adjacent roads. It was invested Tk. 1918.28/ha on average which was $1.66 \%$ of the total investment for fish culture purposes in floodplain projects. As the floodplain area had lower land elevation, it became flooded regularly depending on the water level in the adjacent rivers. To convert a piece of floodplain area into aquaculture project, it required encircling the area by constructing good embankment and sluice gates. Such construction of common infrastructure happens to be very expensive in low-lying areas and often impossible for the community. Most of the projects had to invest big amount of money for infrastructure development during the inception year. The average amount of cost for both nursery and land lease was fond Tk. 9490.08 /ha and it was $8.23 \%$ of the total investment. 
Table 1. Detailed description of costs and returns of fish culture in floodplain

\begin{tabular}{|l|c|c|}
\hline Cost items & Amount (Tk/ha/year) & $\%$ of the total cost \\
\hline Construction of embankment & 1918.28 & 1.66 \\
\hline Nursery and land lease & 9490.08 & 8.23 \\
\hline Fertilizer and lime & 7351.54 & 6.38 \\
\hline Fingerlings & 11879.18 & 10.30 \\
\hline Feed & 50255.41 & 43.58 \\
\hline Office management & 2307.23 & 2.00 \\
\hline Labor and staff wages & 8157.75 & 7.07 \\
\hline Compensation & 3362.13 & 2.92 \\
\hline Harvesting and marketing & 8849.43 & 7.67 \\
\hline Miscellaneous & 11737.49 & 10.18 \\
\hline Total cost (TC) & 115308.55 & 100 \\
\hline
\end{tabular}

Floodplain aquaculture projects tend to stock larger sized fingerlings to optimize growth from the short grow out period. Most of the projects kept over wintering fingerlings for the next year stock. The demand for larger sized fingerlings during the onset of monsoon become very high which has lead the growth of fingerling nursery business around the area. Average input for fertilizer and lime was Tk. 7351.54 /ha and it contributed $6.38 \%$ to the total cost implemented. Both organic and inorganic fertilizer was used in the floodplains. Inorganic fertilizers such as Urea, TSP, SSP and organic fertilizer cow dung were used in these floodplains. The cost for fingerlings was found to be Tk.11879.18/ha on average and it was $10.30 \%$ of the total investment. For stocking the floodplain projects, varieties of fish are chosen from the cultivable species available under current aquaculture in the country. Range of exotic fish species were generally dominant in the stocking list while native species were found about less than $25 \%$ of the total stocking.

The cost of feed comprises the major part of the cost and it was Tk. 50255.41/ha on average and contributed $43.58 \%$ to the investment. Supply of artificial supplementary feed, which can compliment nutritional deficiency, is important to increase fish production. Use of supplementary feed for fish growth has been marked in all cases and the community projects were spending about $40 \%-45 \%$ of their operational cost for feed. Among the feed items used, mustard oil cake, rice bran and meat bone meal were most common.

Office management included various items such as, office house set up, purchase of furniture, electric bill, decoration, pen and papers etc. The cost of office management was found very high, as the projects are a place of mass gathers and meetings and discussions are very common. So it needed a wellestablished office house to keep all the records of the past and present. From the study it was found that the average cost of office management was Tk. 2307.23/ha, which contributed $2 \%$ to the total investment. Both the occasional and permanent labor was appointed for various purposes such as, embankment construction, security and project management.

The committee members were honored by additional money after calculating the final cost-benefit of the year. The committee members were responsible for the welfare of the project so the shareholders offered them that money willingly. Accountants were appointed to keep records and some of the projects also appointed Chartered Accountants to verify the calculations. Cost of labor and staff wages was found Tk. 8157.75 /ha on average, which was $7.07 \%$ of the total cost. The surrounding households were often washed away when the area become flooded in the fully rainy season. If the vegetable or other crops were hampered by fish culture then the farmers were given the equal money of those crops. In certain area, some people were benefited from their own ditches before fish culture. So, they were also given compensation for their loss of that money. The study showed that, it was given Tk. 3362.13 /ha on average and it was $2.92 \%$ of the total cost. From the study it was found that a number of labors were appointed both for fish harvesting and marketing. The fish was marketed in the distant places such as, Chittagong, Sylhet and Dhaka etc. so it required high amount of money. The wholesaler and the Aratdars, 
who came during the fish tender, were entertained that increased the total cost. It was fond Tk. $8849.43 /$ ha on average and it contributed $7.67 \%$ to the total cost. The Miscellaneous cost included the following items such as social development, donation for Madrasha, Mosques, construction of deep tube wells and sluice gates, guest entertainment etc. it was Tk. 11737.49 /ha on average and it contributed $10.18 \%$ to the total cost.

\section{Fish production}

The fish production obtained from the flood the floodplain aquaculture projects in and around Daudkandi area ranges from 1.5 to 2.9 ton/ha. It is very encouraging for the landowners and farmers to have the income coming additionally from their lands within 4-6 months period usually left fallow. There are some projects reported to produce exceptionally high ranging from 2.5 to $3 \mathrm{mt}$./ha. Pankowri Fisheries in Eliotgonj and Shoibal Fisheries in Roypur are the examples of such exceptionally productive projects. It was found that the average fish production from the study area was $2920.43 \mathrm{~kg} / \mathrm{ha}$. Both cultured and naturally grown fish species were found in the study area, which yields a total of 27 different fish species (Table 2). Wahab et al. (2007) estimated the annual yield of 2757, 3405 and $3706 \mathrm{~kg} / \mathrm{ha}$ by establishing sanctuaries in Dopi beel and Joanshahi beel in Kishorgonj. Ahmed et al. (2007) reported the standing crop ranged from 245 to $1047 \mathrm{~kg}$ (av. $584 \mathrm{~kg}$ ) and 270 to $630 \mathrm{~kg}$ (av. $433 \mathrm{~kg}$ ) from a mean area of 40 decimal katha for the first and second harvesting respectively. MPO (1984) cited that the major river systems of Bangladesh represent a per hectare production of $240 \mathrm{~kg}$ and the floodplain production figure of $50-200 \mathrm{~kg} / \mathrm{ha} / \mathrm{yr}$ has assumed. The estimated production per ha from dewatered beels can be quite high as $1819 \mathrm{~kg} / \mathrm{ha} / \mathrm{yr}$; the range has been reported to be $100-600 \mathrm{~kg} / \mathrm{ha}$ in rivers whereas, floodplain productivity tends to be some what higher and in some cases has been reported to be as high as $6000 \mathrm{~kg}$ per hectare. Gupta et al. (1991) reported the production of fish in floodplains as $1000 \mathrm{~kg} / \mathrm{ha}$ under natural condition.

\section{Return from floodplain fish production}

Total return is the monetary value of different items such total production fish (Kg), sacs (of fertilizer, lime and feed). Sometimes additional income was gained such as, donation and fine of the fish poachers. All of the income was gained by multiplying the total amount of yields by their respective market prices. The detailed breakdown of species wise production and their monetary values are illustrated in Table 2 . Total income from fish and other sources was Tk. 176385.49 /ha on average. Net returns were calculated considering full costs. Annual net return in full cost was Tk. 61076.94 /ha on average considering all farms together. Ahmed (2005) found that the total income, total cost and net profit gained from the Bhandardah baor in Chuadanga was Tk. 18469.38, 10093.00 and 8375.60 /ha respectively with the stocking density of 2600 fingerlings per ha. Hossain (2006) estimated a net profit of Tk.24988 from floodplain aquaculture in Daudkandi upazilla in 2005. Khaleque et al. (1998) reported that, the average cost for fish production under semi-intensive culture and management was estimated to be Tk. 86913.17 against the gross income of Tk. 166350.46 indicating a net return of Tk. 79437.29. The benefit cost ratio was 1.91.

\section{Comparison between Bank interest and profit gained from fish culture in floodplain}

If any person saves taka 100,000 in a bank as fixed deposit, after a successive year-end he will get Tk. 12,000 as interest (according to City Bank at $12 \%$ rate). But he has to pay $10 \%$ of this interest to the Government as income tax. On the contrary, in the study it is found that, if Tk. 100,000 is invested for fish culture in floodplains then it is possible to earn Tk. 52,968.26. So, it may be concluded that fish culture is about 5 times profitable than savings in the Banks. A comparison between bank interest and profit earned from fish culture in floodplains per 100,000 taka is shown in Fig. 1. 
Table 2. Detailed break down of species wise production and their incomes per ha area

\begin{tabular}{|c|c|c|c|c|}
\hline Fish species & $\begin{array}{c}\text { Average } \\
\text { production (Kg/ha) }\end{array}$ & $\begin{array}{l}\text { Average selling } \\
\text { price }(\mathrm{Tk} . / \mathrm{Kg})\end{array}$ & $\begin{array}{c}\text { Average income } \\
\text { (Tk./ha) }\end{array}$ & $\begin{array}{l}\text { Contribution of the } \\
\text { total income (\%) }\end{array}$ \\
\hline Silver carp & $626.35 \pm 199.59$ & $46.51 \pm 7.66$ & 29134.20 & 16.75 \\
\hline Bighead carp & $235.66 \pm 124.85$ & $41.51 \pm 10.26$ & 9782.08 & 5.63 \\
\hline Catla & $68.59 \pm 65.26$ & $80.55 \pm 14.62$ & 5524.66 & 3.18 \\
\hline Rui & $252.32 \pm 136.18$ & $63.01 \pm 7.41$ & 15897.51 & 9.14 \\
\hline Mrigal & $270.18 \pm 175.27$ & $65.24 \pm 2.90$ & 17627.48 & 10.14 \\
\hline Carpio & $208.53 \pm 118.06$ & $65.42 \pm 4.08$ & 13642.47 & 7.85 \\
\hline Thai Sar Punti & $73.59 \pm 59.71$ & $64.17 \pm 16.09$ & 4722.34 & 2.72 \\
\hline Monosex (Tilapia) & $516.47 \pm 278.35$ & $67.64 \pm 6.93$ & 34932.10 & 20.09 \\
\hline Black carp & $15.47 \pm 12.73$ & $61.00 \pm 7.13$ & 943.51 & 0.54 \\
\hline Kalibaush & $47.33 \pm 41.01$ & $67.78 \pm 5.89$ & 3207.80 & 1.84 \\
\hline Gaunia & $40.60 \pm 38.08$ & $58.23 \pm 2.47$ & 2364.30 & 1.36 \\
\hline Pangus & $81.39 \pm 67.81$ & $43.11 \pm 5.17$ & 3508.65 & 2.02 \\
\hline Piranha & $66.06 \pm 44.50$ & $81.62 \pm 3.72$ & 5392.06 & 3.10 \\
\hline Grass carp & $49.74 \pm 29.40$ & $67.09 \pm 12.18$ & 3337.50 & 1.92 \\
\hline Chital & $4.00 \pm 2.11$ & $152.70 \pm 33.72$ & 611.48 & 0.35 \\
\hline Air & $22.86 \pm 19.19$ & $173.09 \pm 58.19$ & 3957.48 & 2.28 \\
\hline Cross & $118.21 \pm 102.80$ & $52.55 \pm 8.68$ & 6211.69 & 3.57 \\
\hline Sub- Total & 2697.35 & & 160797.30 & 92.47 \\
\hline Shol & $11.33 \pm 10.49$ & $112.63 \pm 19.83$ & 1276.55 & 0.73 \\
\hline Taki & $12.11 \pm 11.47$ & $50.71 \pm 15.74$ & 614.12 & 0.35 \\
\hline Mola & $58.17 \pm 52.23$ & $50.00 \pm 15.25$ & 2908.33 & 1.67 \\
\hline Tengra & $2.96 \pm 1.92$ & $51.30 \pm 19.07$ & 151.84 & 0.09 \\
\hline Baim & $15.73 \pm 14.62$ & $94.28 \pm 30.15$ & 1483.38 & 0.85 \\
\hline Koi & $5.11 \pm 4.77$ & $179.31 \pm 40.10$ & 915.92 & 0.53 \\
\hline Shing & $3.94 \pm 3.59$ & $223.42 \pm 63.87$ & 881.03 & 0.51 \\
\hline Foli & $2.76 \pm 2.32$ & $89.47 \pm 29.19$ & 246.73 & 0.14 \\
\hline Punti & $29.76 \pm 25.80$ & $38.14 \pm 1.58$ & 1135.24 & 0.65 \\
\hline Gura & $73.70 \pm 60.32$ & $36.29 \pm 2.37$ & 2674.81 & 1.54 \\
\hline Chingri & $5.98 \pm 1.31$ & $95.77 \pm 48.47$ & 572.96 & 0.33 \\
\hline Boal & $1.51 \pm 1.43$ & $150.19 \pm 17.17$ & 227.28 & 0.13 \\
\hline Sub-Total & 223.08 & & 13088.18 & 7.53 \\
\hline Total & 2920.43 & & 173885.49 & 100 \\
\hline From miscellaneous sources & & & 2500 & \\
\hline Total return (TR) & & & 176385.49 & \\
\hline Total cost (TC) & & & 115308.55 & \\
\hline Net income (TR-TC) & & & 61076.94 & \\
\hline BCR & & & 1.53 & \\
\hline
\end{tabular}

* Mean \pm SD

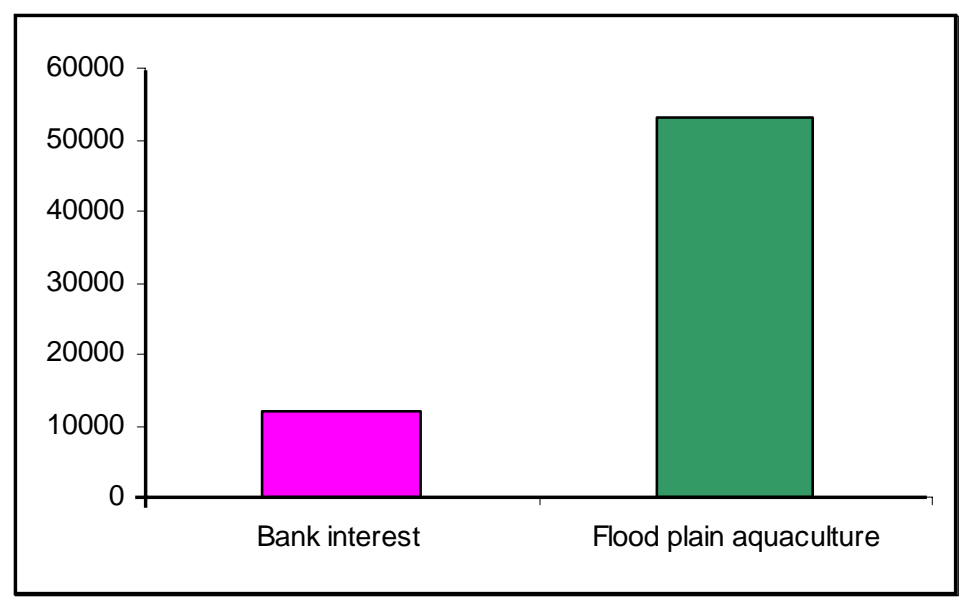

Fig.1. Comparison between bank interest and profit earned from fish culture in floodplains (per 100,000 taka) 


\section{Fish Marketing}

Community managed the marketing of fish produced from the projects most efficiently by themselves. Project management had developed good marketing network among aratders from different fish landing centers of Chittagong, Sylhet, Feni and Dhaka. Production Managers from different projects collected market information every day through mobile phone and operate daily fish harvesting as per market demand. Harvested fish were stored species wise and graded as per size before weighing and packing. Bamboo baskets and polythene sheets were used to pack the fish before loading into truck. Crushed ice at the ratio of 1:2 (ice: fish) was used for the fish 6-8 hours transport. In terms of technical point of view, there were several weaknesses in the post harvest handling of fish. Harvesting started generally from afternoon and landing started 2-3 hours later. Harvested fish was left couple of hours without ice and handled roughly during sorting and weighing before they were loaded in truck and started for market around $10.00 \mathrm{pm} .4$ mounds (mound $=37.5 \mathrm{~kg}$ ) of fish were loaded with inadequate ice in each bamboo basket for transportation when the fish at the bottom were supposed to be damaged physically and deteriorates quality. There have been good handling, icing done timely and adequately, and physical damages were avoided by using alternative smaller baskets, certainly that would have fetched more money for the community. Innovative ideas in harvesting and transporting system were also observed in couple of projects. Instead of harvesting in the afternoon, they harvested from the morning and keep fish alive inside net kept in water. In the evening, the live fish were loaded in to the truck without ice and transported to the market. The fish obtained better shelf life by this process and sold in better price. Moreover, the cost for ice could be saved by this system. More careful observation, however, was needed to comment on the effectiveness of the system.

\section{Resource productivity of floodplain fish culture}

The tabular method was used to estimate the total and net returns from floodplain fish culture. The focus was made to construct a quantities analysis of floodplain fish production in the framework of a production analysis. This analysis is expected to provide a more clear view about the intensity and productivity of resources employed in fish production. In the study area, factors affecting production of fish in floodplains the following inputs were explanatory variables, which were responsible for producing fish. Cobb-Douglas equation was used to explore the possible relationship between the production of fish in floodplains and the inputs used. The results of Cobb-Douglas production equation has been showed in Table 3 .

Table 3. Estimated values of regression Co-efficients and related statistics of Cobb-Douglas Production model

\begin{tabular}{|l|c|c|}
\hline Explanatory variables & Regression Co-efficients & Standard Error \\
\hline Constant & 1.571 & 2.237 \\
\hline Area $\left(\mathrm{X}_{1}\right)$ & -0.034 & 0.047 \\
\hline Construction of embankment $\left(\mathrm{X}_{2}\right)$ & $0.134^{\star \star \star}$ & 0.063 \\
\hline Nursery and land lease $\left(\mathrm{X}_{3}\right)$ & $0.088^{\star \star \star}$ & 0.043 \\
\hline Fertilizer and lime $\left(\mathrm{X}_{4}\right)$ & $0.169^{\star \star}$ & 0.069 \\
\hline Fingerlings $\left(\mathrm{X}_{5}\right)$ & 0.123 & 0.124 \\
\hline Feed $\left(\mathrm{X}_{6}\right)$ & $0.517^{\star}$ & 0.079 \\
\hline Office management $\left(\mathrm{X}_{7}\right)$ & -0.076 & 0.054 \\
\hline Labour and staff wages $\left(\mathrm{X}_{8}\right)$ & 0.021 & 0.073 \\
\hline Compensation $\left(\mathrm{X}_{9}\right)$ & -0.045 & 0.074 \\
\hline Harvesting and marketing $\left(\mathrm{X}_{10}\right)$ & -0.037 & 0.107 \\
\hline Miscellaneous $\left(\mathrm{X}_{11}\right)$ & $0.164^{\star \star \star}$ & 0.086 \\
\hline$\sum$ bi & 1.023 & \\
\hline R adjusted & 0.892 & \\
\hline F value & 15.28 & \\
\hline
\end{tabular}

${ }^{* * *}=$ Significant at $10 \%$ level, ${ }^{* *}=$ Significant at $5 \%$ level, ${ }^{*}=$ Significant at $1 \%$ level 
The co-efficient of multiple determinations, value of $\mathrm{R}^{2}$ is 0.892 , which indicates that $89.2 \%$ of the variation in the floodplain fish production is explained by the independent variables incorporated in the model. The values of $R^{2}$ were significantly higher. The high value of $R^{2}$ was indication that the inputoutput data were collected from those farms who followed a very much similar production practices with uniform system of floodplain water body management. A slightly higher value of $R^{2}(0.932)$ was noted by Islam (1987) in Gazipur district. On the other hand, Saha et al. (1995) estimated the value of $R^{2}$ to be 0.534 and 0.492 in Ghatail and Pakundia Thana respectively.

The $\mathrm{F}$ value of the equation was satisfactory, as it was significant at $1 \%$ level implying that variation in fish production in floodplain depends among other factors on the variables already included in the model. In the regression equation eleven explanatory variables were hypothesized. Out of these variables, only four coefficients had negative sign while the rest seven coefficients showed positive sign. The coefficients bearing positive sign made positive impact on the farm income, while the coefficients with negative sign decrease income. The return to the scale $\sum$ bi was obtained as sum of coefficients of inputs used. In the production function, the return to the scale stood at 1.023, which indicate that if all the specific inputs would necessary by $1 \%$, the farm income would increase by $1.023 \%$ for floodplain fish culture.

Fish production is a function of stocking density, species combination, fertilization, feeding, water quality management, and disease control and culture methods. Improving the production technology through the manipulation of both cultural can increase fish production in floodplains and management practices. Generally the quantities of input used in small ponds are higher than the medium ponds followed by large pond (Molla et al., 1990), but the large ponds give the higher production than the medium ponds followed by the small ponds. On the contrary, Biswas (1990) reported that medium and small ponds had the higher gross and net return because of using higher doses of inputs in combination compared to large farm. But in case of floodplains fish culture is too difficult to manage a large area due to inadequate manpower. It requires high investment for a large project, which may be unproductive at any cases.

\section{Resource use efficiency}

The resources are considered to be efficiently used as well as profit will be maximized when the ratio of marginal value product (MVP) to marginal factor cost (MFC) approaches one or in other words MVP and MFC for each input are equal. When the marginal physical product (MPP) is multiplied by the product price, it is called marginal value product (MVP). (MFC) is the price of one unit of input. From the estimated regression, one can study the ability of the floodplain project owners in allocating resources for floodplain fish production. In order to test this efficiency the ration of MVP to MFC for each input was calculated by some algebraic manipulation and tested for its equality to 1 i.e., $\frac{M V P}{M F C}=1$

It can be observed from Table 4 that the ratio of MVP and MFC of 7 factors were positive while 3 were negative. It indicates that there is a little scope for the project owners to increase the floodplain fish production per hectare per year by reallocating the inputs. It is evident that the project owners generally made excessive use of inputs such as office management, compensation, harvesting and marketing.

Table 4. Marginal productivity and resource use efficiency

\begin{tabular}{|l|c|c|c|}
\hline Factors & $\begin{array}{c}\text { Marginal value } \\
\text { product (MVP) }\end{array}$ & $\begin{array}{c}\text { Marginal factor } \\
\text { cost (MFC) }\end{array}$ & $\begin{array}{c}\text { Marginal value product /Marginal } \\
\text { factor cost (MVP/ MFC) }\end{array}$ \\
\hline Construction of embankment & 0.134 & 1.00 & 0.134 \\
\hline Nursery and land lease & 0.088 & 1.00 & 0.088 \\
\hline Fertilizer and lime & 0.169 & 1.00 & 0.169 \\
\hline Fingerlings & 0.123 & 1.00 & 0.123 \\
\hline Feed & 0.517 & 1.00 & 0.517 \\
\hline Office management & -0.076 & 1.00 & -0.076 \\
\hline Labour and staff wages & 0.021 & 1.00 & 0.021 \\
\hline Compensation & -0.045 & 1.00 & -0.045 \\
\hline Harvesting and marketing & -0.034 & 1.00 & -0.034 \\
\hline Miscellaneous & 0.164 & 1.00 & 0.164 \\
\hline
\end{tabular}




\section{Benefit Cost Ratio}

The average cost of fish production in the surveyed area was estimated Tk. 115308.6 against the total income Tk. 176385.49 indicates the net return of Tk.61076.94. The benefit cost ratio (BCR) was found to be 1.53 in the present study. A much similar level of BCR was noted (RMC, 1995) for credit contact and demonstration farmers of Mymensingh Aquaculture Extension project (MAEP). Shohel (1998) estimated the value of BCR to be 2.02, which revealed that for investment of 1.00 taka, the economic return is 2.0 taka. The BCR is comparatively lower than pond fish culture because of floodplain, it requires some additional management such as, construction of embankment, sluice gate, office management etc. which increase total cost against the total return.

\section{Conclusion}

Fish production in floodplain area was found highly profitable. But it was evident that some projects stocked the Red piranha and Thai koi, which may cause havoc in our fish biodiversity. The project owners have to be more conscious for using the inputs in such way that it may limit the total cost to gain more profit. The number of fish sanctuaries should be increased during dry season to get more profit from natural fish species. Therefore, it is important that the DoF and local NGOs should come forward to provide technical support to the floodplain projects. Otherwise, the projects may not be in position to maintain their present level of fish production. The study suggested that, if a larger number of projects could be selected and grouped as most efficient, moderately efficient and less efficient, the finding from production function analysis could reveal the yield increasing factors more clearly. Future research can be advanced in this direction.

\section{Acknowledgement}

The authors are highly grateful to the floodplain project owners, DoF personnel and respective NGO SHISUK who spared their valuable time for providing information, co-operation and necessary contribution.

\section{References}

Ahmed, M. 1997. Socio-Economic and Policy issues in the floodplain fisheries of Bangladesh. In: Tasai and M. Y. Ali (editors), open water fisheries of Bangladesh, The university Press Limited, Dhaka- 1000.89-98 pp.

Ahmed, M., Latifa, G.A., Hossain, M.B. and Islam, M.S. 2007. Relationship of the size of sanctuaries and dry season water area in Goalkhola-Hatiara beel, Narail. Bangladsh J. Fish., 30:145-151.

Ahmed, K. 2005. Baor management systems in Chuadanga. An M. S. thesis submitted to the fisheries and Marine Resource Technology Discipline, Khulna University, Khulna, $16 \mathrm{pp}$.

Bayley, P.B. 1988. Factors affecting growth rates of young tropical floodplain fisheries: seasonally and density-dependence. Envir. Biol. Fish. 21: 127-142.

Biswas, N.C. 1990. Socio-economic study of pond fish farming in some selected areas of Jhenaidah district. An M. S. thesis submitted to the department of Agricultural Economics, Bangladesh Agricultural University, Mymensingh. $89 \mathrm{pp}$.

DFID. 2000. Aquatic resources management for sustainable livelihood of poor people. A discussion paper by Department for International Development (DFID), NACA, Bangkok, Thailand, 12 p.

DOF. 2004. Fishery Statistical Year Book of Bangladesh, Department of Fisheries, Bangladesh. 41 pp.

DOF. 2006. Matshya Sompod Unnoyoan Projukti Sohayika. 59 pp.

Gupta, R.A., Mandal, S.K. and Paul, S. 1991. Methodology for collection and estimation of inland fisheries statistics in India. Central Indian Capture Fisheries research Institute, Barrakpore 743101, West Bengal, India. Bull. No. 58, 8-64 pp.

Heady, E.O. and Dillion, J.L. 1996. Agricultural production functions. Iowa State University Press. Ames, lowa, USA. 228-232 pp.

Hossain, B. 2006. Management of floodplain fish culture at Daudkandi Upazilla. An M. S. thesis submitted to the Fisheries and Marine Resource Technology Discipline, Khulna University, Khulna. 21pp. 
Islam, M.S. 1987. Input-output relation of pond fish culture in four selected districts of Bangladesh. Bangladesh J. Ext. Edu., 2(2): 39-45.

Khan, M.A. 1997. Ecology of floodplains in the north-eastern region of Bangladesh. In: Tasai and M. Y. Ali (editors), Open water fisheries of Bangladesh. The university Press Limited, Dhaka- 1000.153-172. pp.

Khaleque, M.A. 2006. Fish culture in floodplain following Daudkandi modle. Matshya Sompod Unnoyoan Projukti Sohayika. 5 pp.

Khaleque, M.A., A. Masud, K.S. and Mirza, J.A. 1998. Economics of fish production under semi-intensive culture and management. Bangladesh J. Train. Dev., 2(1-2): 81-86.

$\mathrm{MACH}, 1999$. Management of Aquatic-Ecosystem through Community Husbandry (MACH) Project, Dhaka-1212, 59 p.

Middendorp, H.A.J. and Balarin, J.D. 1999. Fisheries enhancement and participatory aquatic resources management: two types of management in the ox-bow lakes in Bangladesh, In: H. A. J. Middendrop, P. Thompson and R. S. Pomeroy (editors), sustainable inland fisheries management in Bangladesh. ICLARM Conference Proceedings 58, Manila, 31-34 pp.

Mollah, A.R., Chowdhury, S.N. I. and Habib, A. 1990. Input-output relation in fish production under various pond size, ownership pattern and constrains. Bangladesh J. Train. Dev., 3(2): 54-60.

Mollah, A.Q. 2001. Seasonal fish culture management in floodplains. 10pp.

MPO (Master Plan Organization). 1984. Second Interim Report-Vol.-Fisheries. Master Plan Organization for National Water Planning, Ministry of Irrigation, Water Development and Flood Control, Government of Bangladesh, Dhaka. 25-34 pp.

RMC (Resource Management Consultant). 1995. Impact study on Mymensingh Aquaculture Extension Project Phase-1. 69/C, Green road, $2^{\text {nd }}$ floor, Dhaka-1205.

Saha, N.C., Islam, M.S. and Saha, J.K. 1995. Economics of pond fish production in some selected areas of Bangladesh. Bangladesh JAqua., 17-19 (1-2): 13-18.

Shang, Y.C. 1981. Aquaculture Economics. Westview Press inc. United States of America. 18 pp.

Shohel, N.U. 1998. A socio-economic study of pond fish production in some selected areas of Noakhali district. An M. S. thesis submitted to the Department of Agriculture Economics, Bangladesh Agricultural University, Mymensingh. 91 pp.

Tsai, C. and Ali, M.Y. 1997. Open water fisheries in Bangladesh. The university Press Limited, Dhaka-1000, 212 p.

Wahab, M.A., Habib, M.A.B., Azhar, S.A., Dewan, S. and Mustafa, M.G. 2007. Impacts of fish sanctuaries on production and biodiversity of fish and prawn in Dopi beel, Joanshahi haor, Kishorgonj. Bangladesh J. Fish., 30: 23-36. 